\section{Woman of the}

\section{Decades}

\section{The Legendary Louise Seaman Bechtel}

LISA VON DRASEK

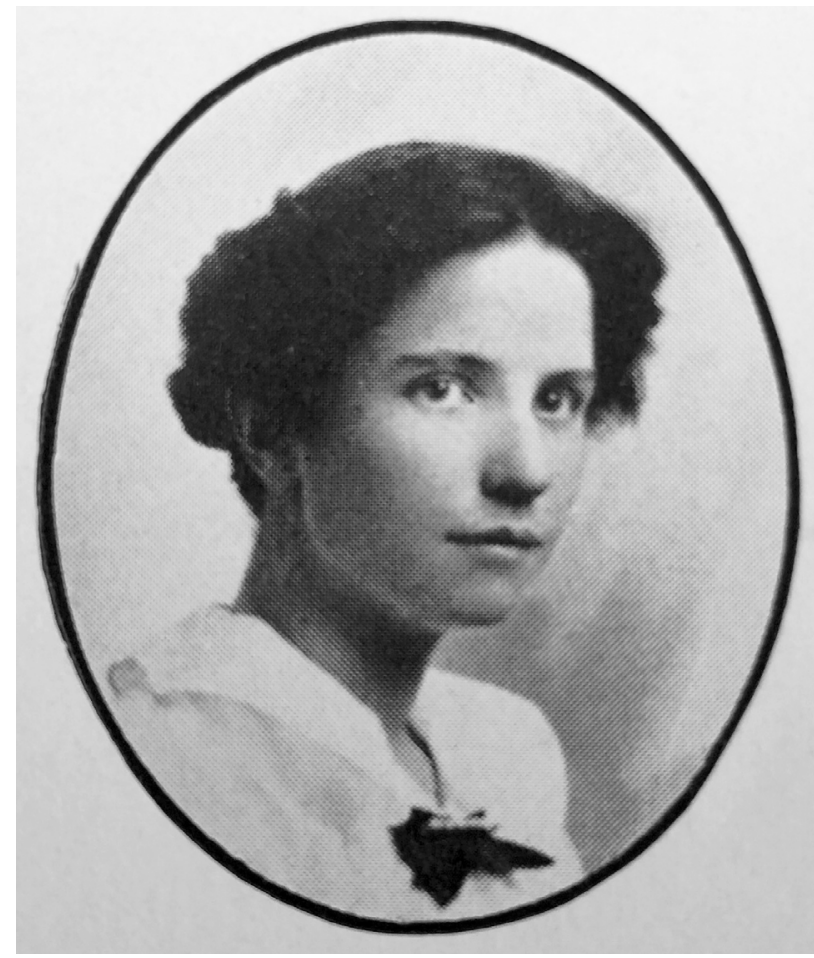

Louise Seaman Bechtel in her Vassar graduation picture, 1915 (Baldwin Collection, University of Florida).
W hen I found out I was awarded ALSC's Bechtel Fellowship to conduct research in the Baldwin Library of Historical Children's Literature at the University of Florida Libraries in Gainesville, I was honored, thrilled, and excited. I was also curious to learn more about the person for whom my fellowship was named.

Louise Seaman Bechtel (1894-1985) (correctly pronounced, I learned, with the emphasis on the first syllable, BECK-tull) headed the first children's book division of a publisher. ${ }^{1}$ The Baldwin holds her papers; therefore I had the opportunity to read Bechtel's unpublished memoir, letters, lecture notes, family photos, and even a scrapbook of cards as well as art sent to her by her authors and illustrators. I discovered a woman who, in the words of Professor Kaye Vandergrift of Rutgers University, was an example of "unquestionably strong, dedicated, often highly opinionated women who fought to establish and to preserve service to children in libraries, while developing a national and international presence for their philosophy and practices." ${ }^{2}$

One hundred years ago in 1919, the first children's book department in the United States was established by the Macmillan Company, headed by the then young and unknown editorin-chief Louise Seaman. In 1928, she married and became Mrs. Edwin Bechtel. ${ }^{3}$ (I refer to her as Bechtel throughout this essay.) Bechtel was raised in a middle-class home, attending very good public schools (Erasmus High) without any career ambitions as was typical of her gender, economic class, and cultural norms of the early 1900s. A high school teacher recommended that she attend a private school, Packer Collegiate for her senior year. This experience expanded her horizons and she was encouraged to attend Vassar College.

A member of the class of 1915, Bechtel spent her college years reporting and editing school journals and newspapers, such as the Vassar Miscellany. Upon graduation, she was considered unemployable as a journalist because she was a woman. ${ }^{4}$ She finally obtained a teaching position at Miss Glendinning's School in New Haven, Connecticut, during which time she attended graduate classes in history and English at Yale University. After three years, at age twenty-four, she was pushed out of the school by a new headmistress who said, "If you haven't married after two and a half years here, it's time you tried New York." ${ }^{5}$

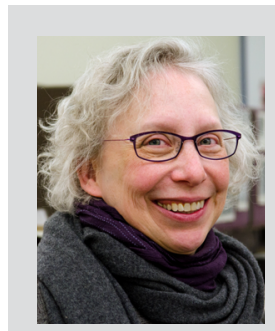

Lisa Von Drasek is Curator of the Children's Literature Research Collections at University of Minnesota. She is a frequent lecturer on storytelling and folklore, collection development, children's literature, and library services to children. She blogs at Blue Ox Review. Lisa's publications include Writing Boxes: The Reading/Writing Connection in Libraries. 


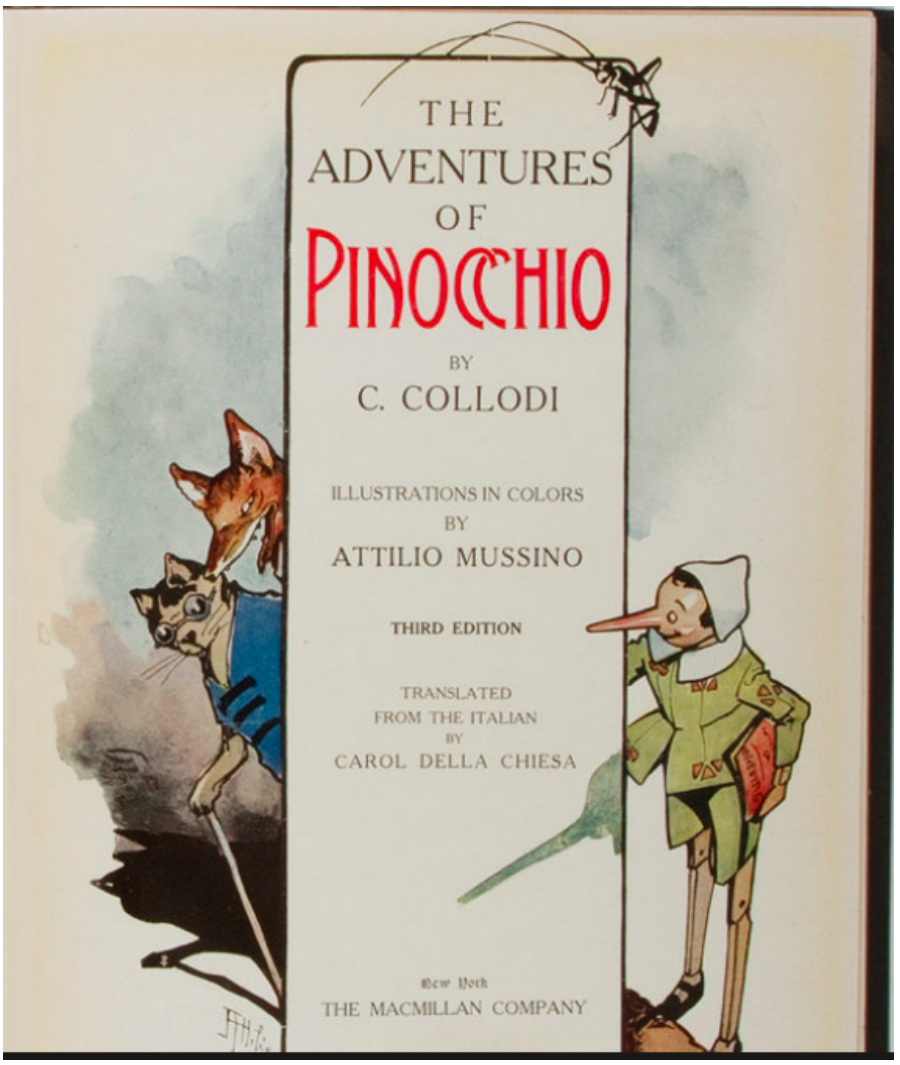

Bechtel writes "this tactless dismissal was a shock," but she used this opportunity to beg for an interview at Macmillan Publishing Company. ${ }^{6}$ Coincidentally she ran into her dear friend Rebecca Lawrence from her Miscellany days. Becky, as she was known, was one of two respected manuscript readers at Macmillan, and she recommended Bechtel for a position in the advertising department.

The head of advertising was Scudder Middleton, whom Bechtel described as a famous figure of the twenties, a moody, proud poet, and author of one slim volume. ${ }^{7}$

On Bechtel's first day at work she recalled that "her boss came in late with a hangover following dinner with Edna St. Vincent Millay the previous evening. When the boss saw Seaman, he roared, 'What's THAT? Not another female for this harem of mine! What can I give you to do . . I know! Read the catalog! No one else ever has done it."”8

To understand the obnoxiousness of the advertising head's directive, we must consider the magnitude of the task. Macmillan was the largest English language publisher of the time. The catalog was a sales tool of hundreds of titles ranging from fiction to academic texts to philosophy and how-to with the random children's book embedded in between. Each editorial department was responsible for the titles and advertising department responsible for placement and copy. It would be absurd to think that anyone except a copy editor had read it from cover to cover, including all the previously published titles (the backlist).

\section{Macmillan Books for Boys and Girls}

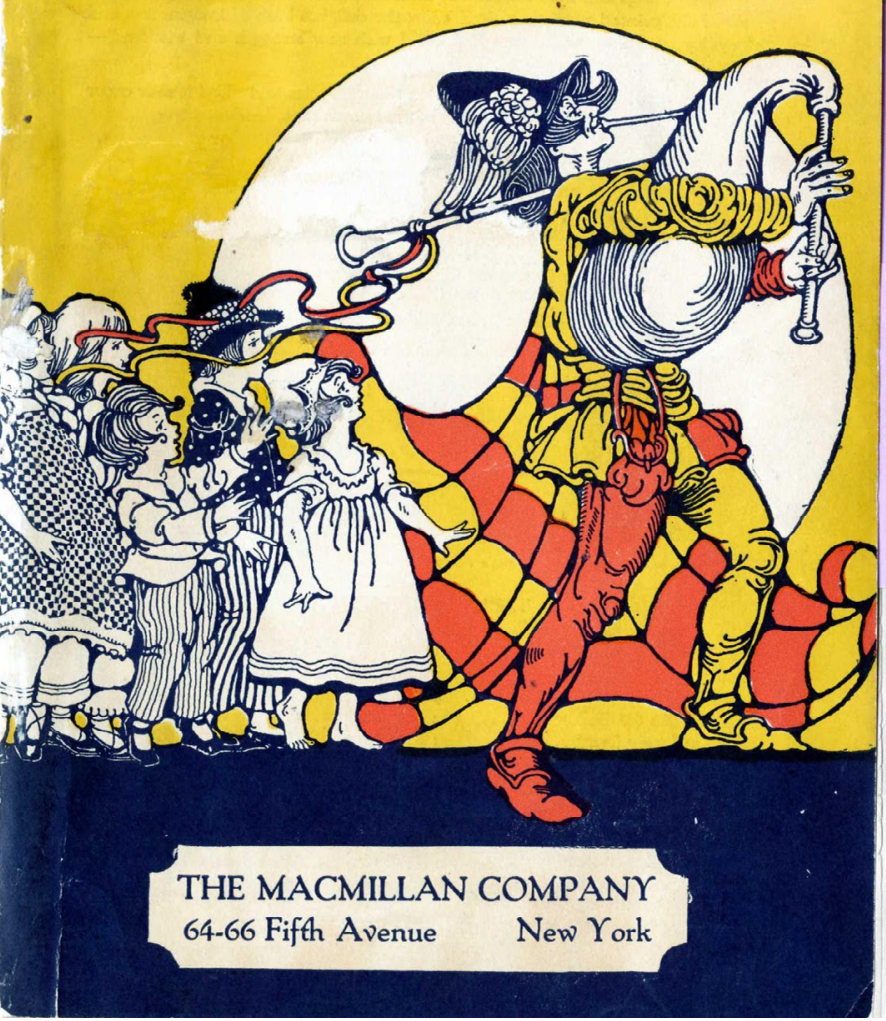

And read the catalog she did. Bechtel went to work, reading the catalog, writing copy, and for wicked fun, composed a "Sonnet to the Catalogue." Her dear friend Becky made sure that the sonnet circulated throughout the company. ${ }^{9}$

The sonnet caught the eye of Macmillan's president, George Brett, who moved her to the education department of the company for a brief time. ${ }^{10}$

"One day, Mr. Brett summoned me and spoke in a sort of despairing irritation of his important new department for 'juvenile' books. He had tried a young man there briefly, who was a flop. 'I suppose that's a subject on which a woman might know something.' Swallowing my ire, I replied that my teaching might have prepared me for it." 11

At age 25, Bechtel was an experienced progressive educator, a skilled reporter, a writer of advertising and promotional copy, and a passionate book woman with a demonstrated sense of humor. She was uniquely suited for the task of heading the new Department of Books for Boys and Girls. Bechtel held the position for the next fifteen years. She was given the position but not the title. This was 1919, and women didn't even have the right to vote yet. 
When the tenth anniversary of Macmillan's Children's Department arrived, Brett wrote that he recalled thinking that children's books would benefit from separate editorial supervision. The new department head would require a person who could do editorial, design, marketing, and understand children's teachers and librarians' needs in literature.

"I believe that children's books are perhaps more important than any other kind. Through these books one reaches young minds at the plastic age when moral character is being formed. Hence the importance of their selection and editing cannot be overestimated," he wrote. ${ }^{12}$

Unfortunately, when Brett offered her the position, he added that while she would be the department head, "for the present we shall not make that public, for only men are the head of departments." She would be called editor but had all the responsibilities of a department head of publishing - the list, catalog, and sales. ${ }^{13}$

Another surprise awaited her on her first day at her new desk. As she began to review her inherited list of several hundred titles, she was "casually handed a second job" of trade publicity. ${ }^{14}$ That meant writing the copy for the spring and fall trade lists, getting publicity and photos from authors, and releasing news notes on a regular sheet to the papers for all of the adult books. This work included writing press releases, jacket copy, and quotes and comments for periodicals. It wasn't until Macmillan moved to a new office in 1925 that Bechtel was relieved of these duties.

Bechtel's first task was to mine the Macmillan backlist of more than two hundred fifty children's book titles. The majority were dusty classics that included the standard American editions of Lewis Carroll's Alice's Adventures in Wonderland, Charles Kingsley's Water Babies, Mrs. Molesworth's The Cuckoo Clock, as well as Arthur Rackham fairy tales, and present them attractively to children's book buyers. ${ }^{15}$ At the same time, she was charged with creating the front list of new titles.

Bechtel wrote that to be a children's book editor meant, "the actual conception of the book by the editor and the difficult pursuit of the right author and artist. Always it means detailed supervision of book-making, knowledge types, often the actual pasting up of the pictures and pages, often not only literary editing of the manuscript but a struggle over each stage of the proof-reading, and certainly all one's own proofs." 16

And to be the marketing director of the lists meant "thinking of new kinds of promotion, seeking ideas . . . being alert to special opportunities of each book, encouraging each selling experience that develops in the field." ${ }^{17}$

Unlike the heads of other book departments at Macmillan, "the advertising department wrote no copy for me, nor did they make my catalogues." 18

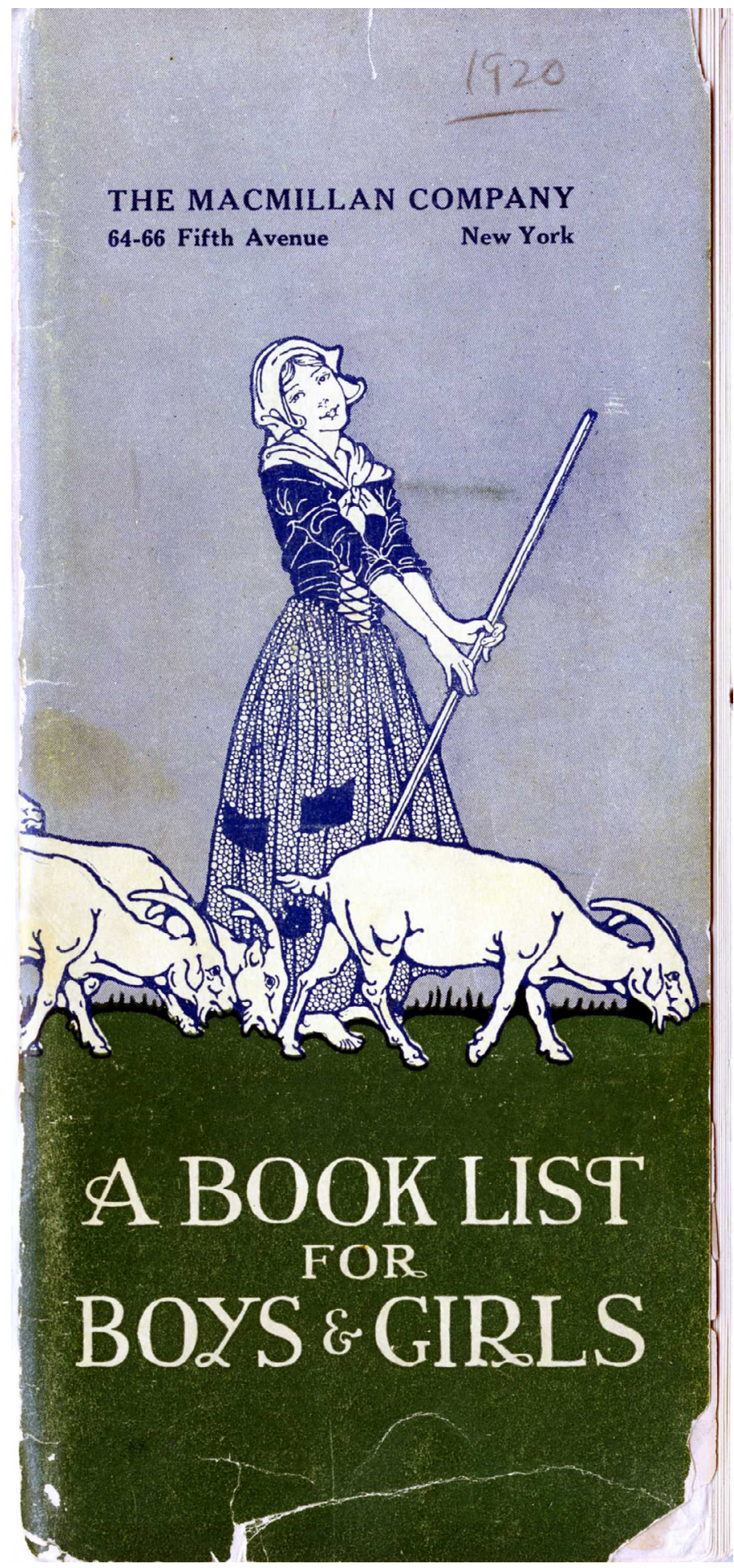

\section{The Catalogs}

Virginia Haviland, who in 1963 became the first specialist in children's literature at the Library of Congress, edited a book of Bechtel's collected writings, Books in Search of Children, published on the fiftieth anniversary of the Department of Books for Boys and Girls. She noted in her foreword that Bechtel felt her best "books" were the bound copies of her Macmillan Children's Book Catalogs. ${ }^{19}$ 
Indeed, the catalogs were masterpieces. Bechtel knew her audience. She needed to get the attention of "the trained librarian who has before she opens it prejudices, sympathies, critical opinions . . . the teacher, who may know very little of modern children's book values, but needs them for definite purposes ... the bookshop person ... who knows books as merchandise ... the parent who approaches it with a very personal point-of-view." 20

Bechtel's experiences in the advertising and education departments of Macmillan had served her well. The first catalog was released in 1920 . She made the best of the backlist by featuring two best-selling authors/illustrators-Padriac Colum, a renowned dramatist, poet, novelist, essayist, biographer, children's writer, a central figure in the Irish literary renaissance, and acclaimed children's book illustrator; and Rackham, known for his romantically illustrated fairy tales. Macmillan's backlist also included Carroll's Alice's Adventures in Wonderland, illustrated by John Tenniel.

"My own experience in catalog-making has been that of continuous experiment. Catalog Number 1 ... was a tall thin list, to fit into a salesman's pocket, also in a big letter envelope mailing. Each became a little book of books." ${ }^{20}$

Atypical of the time, the Children's Department catalogs were not a dry alphabetical listing of titles with publication data. Bechtel understood the importance of grouping titles by category.

An innovator and educator, Bechtel interspersed her own descriptions of the books with pull quotes from classic literature and from educators. She scattered verses of poetry relevant to the titles and embedded positive media review blurbs within title annotations.

To begin the section of school and college stories, she quoted the founding father of progressive education John Dewey: "Growing is not something which is completed in odd moments; it is a continuous leading into the future." ${ }^{21}$

Bechtel strived to reproduce the beauty of her children's books within her catalogs by embedding illustrations. In the first catalog, the subject themes were tied together with Rackham illustrations. ${ }^{22}$

The first list was so successful that it earned Bechtel a significant raise in the summer of $1920 .^{23}$

Each of Bechtel's catalogs displayed changes as she sought unique ways to communicate the importance of children's books to a variety of consumers.

Catalog number 2 for the 1921 list also expands into a digest size. The titles are separated into subject areas. It is a lovely volume with a color cover and color plates featuring upcoming titles, some without publication dates (in place of publication month was the word "preparing"). The color pages were printed in a new French watercolor process. ${ }^{24}$

There is a table of contents directing the reader to subject areas, including folklore and fairy tales, children's classics, storybooks for younger children, and literary quotations. Bechtel begins on the inside front cover with an unsigned note on how to select books, "Ages are indicated by each title. Remember that it is better to give a child a book beyond than one beneath its age. Remember that one good book chosen from this list, to be read and re-read is infinitely better than a shelf full of cheap books and magazines.

"Most of the books for younger children are especially good for reading aloud. More reading aloud, to older as well as younger children, will increase their power of concentration and their sense of the beauty of good English. Advice on individual problems will be given gladly by the Juvenile Department, or by local librarians, or by children's book departments in various stores." 25

I found myself nodding my head as I read and thinking the advice to read aloud is still valid almost a century later. We cannot forget that this catalog was a sales tool; therefore, Bechtel was encouraging buyers to select "good" books. The Macmillan children's books were a bit pricier at \$1.75 and \$2 than the dime novels and five-cent pulp magazines that were printed on highly acidic wood pulp paper, crammed with sensationalized content.

Looking back, Bechtel's beginning lists were certainly of the time and steeped in the Western European canon. The new illustrations were heavily influenced by the Art Nouveau movement and the children's classics by the folkloric Arts and Crafts movement.

By 1931, the catalogs were eagerly received and read. Dr. John Finley, associate editor of the New York Times and former New York Commissioner of Education, wrote to Bechtel, "Thank you for your ever-entrancing catalogue. It should help to lead even grown-ups toward, if not into, the kingdom of Heaven. May I have another?"26

And Lewis Gannet wrote in his book column in the (NY) Herald Tribune, that the new "J" catalogue from Macmillan was "a picture book in itself; a dangerous book for any impoverished parent to let his children see." ${ }^{27}$

Bechtel continued her relationship through the years with Colum, building on The Adventures of Odysseus. The Tale of Troy (later reissued as The Children's Homer) came out in 1918, with new books every year retellings of myths and legends like The Children of Odin and The Golden Fleece, and new tales from old sources like The Boy Who Knew What the Birds Said, The Girl Who Sat by the Ashes, and The Peep-Show Man.

"Humor, fantasy, symbolism," Bechtel wrote, "are part of an ideal way of thinking about the real world." ${ }^{28}$ 
Informational books were equally important to her. Bechtel produced information books like The Goldsmith of Florence (1929) by Katharine Gibson, respected art educator from the Cleveland Museum, and All the Ways of Building-from Karnak to the Empire State (1933) by Louise Lamprey.

Over the years Bechtel was responsible for many firsts, including Popo and Fifina (1932) by Arna Bontemps and Langston Hughes-the first work by an African American author, other than poetry, from a mainstream house; it was illustrated by black cartoonist E. Simms Campbell. "There are no ugly people in Popo and Fifina. Nor does the reader encounter caricatures. Quite noticeably, the characters are described as "black" with appealing physical features. The importance of descriptions that celebrate blackness cannot be underestimated during the period in which the book was published. Many of the pictures of African American children in literature were grotesque and caricatured." 29

Bechtel published every kind of book. Ruth Carroll's What Whiskers Did (1932) may likely have been the first wordless United States picturebook. ${ }^{30}$ Taking advantage of newer photographic printing technologies, she produced Lewis Hine's Men at Work (1932), the first juvenile photodocumentary. ${ }^{31}$ Bechtel was an internationalist also, importing titles from all around the world that were translated from Russian, German, French, Italian, and Czech. ${ }^{32}$

Bechtel produced exquisite gift editions, including a translation of the famous Italian novel, Carlo Collodi's The Adventures of Pinocchio, illustrated by Attilio Mussino (1926).

From 1929 through 1931, Bechtel had edited three consecutive Newbery winners-Eric P. Kelly's The Trumpeter of Krakow, Rachel Field's Hitty, Her First Hundred Years, and Elizabeth Coatsworth's The Cat Who Went to Heaven..$^{33}$ These awards would be evidence of her creative editorial vision and understanding of the craft of bookmaking.

\section{Tireless Promoter}

Bechtel was a tireless promoter always looking for opportunities spread the word about children's books. She had speaking engagements with women's clubs, librarians, homemakers, academics, and booksellers. For example, from October to December 1926, she spoke "at a teachers' college and a social club in Westchester, Pennsylvania; at PTAs in Massachusetts, New York, and New Jersey; at the Newark Art Museum, the Beaver Hill Country Day School, a New York branch library. 'This was not a bad schedule,' she writes in the margin of her itinerary. 'The worst was when I went to Harrisburg and made four talks in one day.'”34

During her tenure at Macmillan, Bechtel even had a weekly radio show, The Story Book Lady, every Monday on WJZ radio in Newark, NJ, in which she promoted Macmillan titles. ${ }^{35}$

\section{The Intersection of Bookselling, Librarianship, Education}

Bechtel's education was not one that prepared her for work in children's books, but she had a cohort of experts to consult, including Bertha Mahony of the Bookshop for Boys and Girls in Boston, Anne Carroll Moore of the New York Public Library, Alice Jordan of The Boston Public Library, and the work of Lucy Sprague Mitchell of the Bureau of Educational Experiments (Bank Street) among many others.

These women did not always agree, but they were the respected experts in the field of children's literature. Their work did intersect-Moore led the charge for children's services in libraries as well as wrote a critical review column in the Bookman. ${ }^{36}$ Bechtel traveled to Boston for meetings with Mahony and Alice Jordan (Mahony's mentor) to understand the children's bookseller's point of view.

It was well-known that there were disagreements as to the philosophy of what constituted a good book for children. Most notable was the "milk bottle" versus Grimm controversy ignited when Lucy Sprague Mitchell published her Here and Now Story Book in $1921 .^{37}$

"Part manifesto, part model for a new approach to writing for preschoolers, this volume . . . became a hotly debated bestseller upon its publication. Mitchell argued that the fairy tales then favored by librarians confused young children, who naturally craved stories about their own here-and-now world, skyscraper cities and all. Mitchell staked her claim on years of direct observation of children at the Bank Street School. Librarians retorted that literature was an art, not a science." ${ }^{38}$

Bechtel was able to straddle both those worlds by publishing beautifully illustrated fairytale classics as well as realistic stories of the everyday, including Mitchell's North America: The Land They Live In for the Children who Live There. ${ }^{39}$

She continued her relationship with Mitchell and the Writers Lab (the incubator where teachers like Margaret Wise Brown honed their craft) throughout her life. There is a lovely invitation held at the Baldwin Library, dated October 11, 1952: "Could I persuade you to talk to the Writers Laboratory informally, more or less gossipy job talk ... Isn't there something from your present job experience or your past-that you would like to spill out and discuss with this group of writers for children?"40

There is no better evidence of the intertwining of interests than the 1928 volume of The Horn Book Magazine (began as a newsletter from Mahony's bookshop) which devoted the majority of the issue celebrating Bechtel and her accomplishments as a publisher, including reproducing pages directly from the Macmillan catalog. ${ }^{41}$ Mahony was shocked to discover that editors from competing houses "far from viewing the issue as a celebration of community achievement, regarded the issue as little more than unpaid advertising." ${ }^{42}$ 


\section{Trailblazing Women}

The 1900s to the early 1920s were heady times for women in the world of children's literature in the United States. The "usual suspects" included:

- Anne Carroll Moore (1871-1961). The librarian was appointed to preside over the New York Public Library's Office of Work with Children in 1906 after ten years as the children's specialist in the Pratt Institute Demonstration School.

- Alice M. Jordan (1870-1960). Best remembered as a pioneering children's librarian, she began work at the Boston Public Library in 1900 and was made custodian of the Children's Room in $1902 .{ }^{43}$

- Bertha Mahony Miller (1882-1969). Bookseller, critic, and founder of one of the first children's bookstores, Bookshop for Boys and Girls in Boston in 1916 and The Horn Book Magazine, ${ }^{44}$ which was started as a newsletter for the shop to "blow the horn" for new children's books recommended for purchase. ${ }^{45}$

- Lucy Sprague Mitchell (1878-1967). Founder of The Bureau of Educational Experiments (later Bank Street College of Education) in New York City with her colleague Harriet Johnson. Their purpose was to combine expanding psychological awareness with democratic conceptions of education. Mitchell was also the founder of the "Here and Now" school of children's book publishing. ${ }^{46}$

\section{The Later Years}

In 1933, Bechtel broke her pelvis in a horseback riding accident. She worked from her hospital bed during the long and painful recovery. A year later in January 1934, Macmillan announced her resignation.

During her convalescent year, her mentor George P. Brett, Sr. had left his position to his son George P. Brett, Jr., who did not support Louise's vision. One factor was that the Depression caused book sales to drop, especially for beautifully made expensive gift editions. Macmillan was ready for a change. ${ }^{47}$

In her memoir, she writes with a little bitterness that "When I 'retired' in 1934 . . . I bequeathed to Miss Patee a 1934 list almost complete." ${ }^{48}$ It was not a secret to her cohorts that she felt pushed out.

Bechtel's post-Macmillan years were filled with children's literature work; she was very busy on the lecture circuit as a teacher, as a book reviewer for the New York Herald Tribune, and as associate editor, and later director, of Horn Book.

In 1964 (after years of no contact with the Macmillan children's department), the newly appointed director of the

\section{A Reflection}

As I reflect on Louise Seaman Bechtel's work in publishing, I am astounded by each groundbreaking action. The most astonishing to me as a former bookseller was her insistence to George P. Brett that she take a sample case of books and her catalog and personally sell the big New York City bookstores and book buyers at the department stores like Macy's.

She was a miserable failure.

In the 1920s, there were no female book reps. The Scribners' buyer was so appalled that a woman was in the hallway standing with the men that he called her from the line to enter his office. Once inside he did not give her a minute to speak but ordered one copy of every title and bid her to leave. (A typical order would be multiple copies of lead titles.)

The department store buyers would not even see her. This did not deter Bechtel; she wanted to experience how her titles were being sold to the buyers of the nation. She insisted on going on the road by train, visiting cities across the United States like Chicago, Minneapolis, and Nashville.

I leave the reader with the image of Louise Bechtel, almost thirty years old, bobbed hair, stockings and heels standing on a train platform with her sample case, ready to sell her list. ${ }^{50}$

Macmillan children's department, Susan Hirschman, (previously of Harper under Ursula Nordstrom) contacted Bechtel. Hirschman, honoring Bechtel as the elder statesman that she was, journeyed up to Westchester once or twice a year, taking tea, talking books, and the upcoming lists.

Hirschman also sent Bechtel review copies and, for the first time in thirty years, Mr. Winkles Room (as Bechtel's home library was called) held new Macmillan titles. In a phone interview with this author, Hirschman (now retired from a forty-seven-year career in children's book publishing, the last as founder of Greenwillow Books, William Morrow), noted that there were many reasons to reach out to Bechtel, not the least was how poorly treated she had been as one of trailblazers of children's book publishing.

Connecting with Bechtel gave Macmillan an opportunity to reinvigorate and republish essential backlist titles as well an celebrate excellence in children's books. ${ }^{49} \&$ 
1. Phone interview with Susan Hirschman, July 9, 2019.

2. Kaye Vandergrift, "Female Advocacy and Harmonious Voices: A History of Public Library Services and Publishing for Children in the United States," Library Trends 44, no. 4 (Spring 1996): 705.

3. James Giblin, “Children's Book Publishing in America: 1919 to Now," Children's Literature in Education 17, no. 3 (1986): 150-58.

4. Giblin, "Children's Book Publishing in America."

5. Bechtel's unpublished memoir manuscript, undated, Baldwin Collection, University of Florida, chapter 3, page 4, https://z.umn.edu/BechtelMemoir.

6. Bechtel's unpublished memoir manuscript.

7. Bechtel's unpublished memoir manuscript.

8. Vassar Encyclopedia: Louise Seaman Bechtel, Vassar College Special Collections, http://vcencyclopedia.vassar .edu/alumni/Louise-Seaman-Bechtel.html.

9. Vassar Encyclopedia: Louise Seaman Bechtel.

10. Leonard S. Marcus, “Six Pioneers,” Publishers' Weekly (July 21, 2008), https://z.umn.edu/MarcusPioneers.

11. Bechtel memoir, chapter 3, page 7 .

12. George P. Brett, Horn Book IV, no. 3 (August 1928): 25-27; actually written by Louise Bechtel and signed by George Brett (unpublished memoir, unpaged).

13. Bechtel memoir, chapter 3 , page 7 .

14. Bechtel memoir, unpaged.

15. Marcus, "Six Pioneers."

16. Louise Seaman Bechtel, Books in Search of Children, Virginia Haviland, introduction, xv.

17. Louise Seaman Bechtel, Books in Search of Children ("When a Publisher Makes a Catalog," speech given at the ALA Convention, 1929, New Haven, Books in Search of Children, 1969, page 11).

18. Bechtel memoir, chapter 7, page 2 .

19. Louise Seaman Bechtel, Books in Search of Children (R.R. Bowker Memorial Lectures; 10th. New York: New York Public Library, 1946), 12.

20. Seaman Bechtel, Books in Search of Children.

21. A Booklist for Boys and Girls (New York: Macmillan, 1920), Kerlan Collections, University of Minnesota, 23.

22. A Booklist for Boys and Girls, 27.

23. Marcus, "Six Pioneers."

24. Bechtel memoir, chapter 9, page 9.

25. Macmillan Books for Boys and Girls, Catalog 2, 1921.
26. John Finley, obituary, New York Times (March 8, 1940), 1.

27. Barbara Bader, "Macmillan Children's Books, 1919-1995," Horn Book Magazine 71, no. 5 (1995): 548.

28. Bechtel memoir, unpaged.

29. Violet Harris, "From Little Black Sambo to Popo and Fifina: Arna Bontemps and the Creation of AfricanAmerican Children's Literature," The Lion and the Unicorn 14, no. 1 (1990): pg 119.

30. Bader, "Macmillan Children's Books, 1919-1995."

31. Bader, "Macmillan Children's Books, 1919-1995."

32. Bader, "Macmillan Children's Books, 1919-1995."

33. Bader, "Macmillan Children's Books, 1919-1995."

34. Louise Seaman Bechtel, Books in Search of Children, Virginia Haviland, introduction, xix.

35. Leonard S. Marcus, Minders of Make-Believe: Idealists, Entrepreneurs, and the Shaping of American Children's Literature, (Houghton Mifflin, 2008), 83.

36. Barbara Bader, "Only the Best: The Hits and Misses of Anne Carroll Moore,” The Horn Book, August 8, 1997.

37. Bechtel, Books in Search of Children, xii.

38. Leonard S. Marcus, The ABC of It: Why Children's Books Matter (Minneapolis: UMN Libraries Press, 2019), www .lib.umn.edu/publishing/monographs/abcofit.

39. Lucy Sprague Mitchell, North America: The Land they Live in for the Children who Live There (New York: Macmillan, 1931).

40. Bechtel Collection, Baldwin Library, Correspondence file. 41. The Horn Book, April 1928.

42. Marcus, Minders of Make-Believe, 64.

43. Jacalyn Eddy, Bookwomen: Creating an Empire in Children's Book Publishing, 1919-1939 (Madison: University of Wisconsin Press, 2006).

44. Alice Jorden, “The Bookshop that is Bertha Mahoney," Atlantic Monthly (June 1929).

45. Bertha Mahoney, The Horn Book Magazine, October 1924, editorial.

46. Bank Street College of Education, Sprague Mitchell Archives.

47. Marcus, Minders of Make-Believe, 64.

48. Bechtel memoir, chapter 7, page 20; Doris S. Patee being her successor.

49. Phone interview, Susan Hirschman, July 9, 2019.

50. Bechtel's unpublished memoir manuscript, chapter 3 , page 4. 